


THE GEOGRAPHICAL DEVELOPMENT OF BOSTON

liv F. I'. (

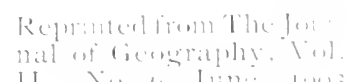

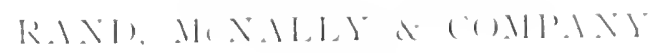

$1 / 1 / 1,1,1)$ 


\section{The JOURNAL of G EOGRAPHY}

HULLLIIED HONTHIS, EXCENT JULY AN1) ALGLST

An Illustrated Magazine Devoted to the Interests of Teachers of Geography in Elementary, Secondary, and Normal Schools

Successor to the Journal of Sitwol fremgrafly. Tol. T.., and the Fulletin of the

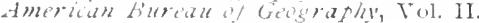

\section{EDITORS}

RICHARD E. DODGE

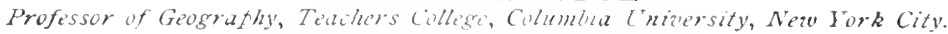

EDWARD M. LEHNERTS

Professor of Geografin, State Tormal Sibod, Hinona, Minnesota.

\section{ASSOCH.4TE EDITOA'S}

CYRUS C. ADAMS.

Geografluial Elitor, .1. I: Sun OTIS W. CALUWELL . Professor of Botany, State Hormal School, Charleston. III. JAMES F. CHAMBERLAIN, Prof. of Geografhy, State tormal Sihool, L's All gele's, Cal. HENRY C. COTWLES . . Associate in Botany, Enizersity of Chicago, Chicago, III. WILLIAM M. DATIS. Proféssor of Geologv, Hare'ard L'mizer sity, Cambriage, Hass. N M. FENNEMAN. . Profés sor of Geology, Uniacrsity of Colorato, Foukder, Colo.

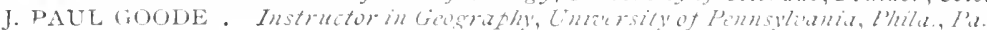

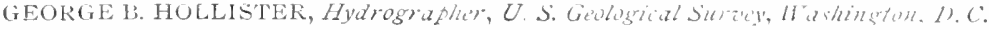

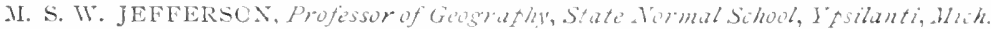
EMORT R. JOHASON, Ast. Prof. of Transpertation and Commerie, Cuar of Finna. EDW. D. JUNES, Asst. Prof. of Commere and Jndustry, Lniz' of Hiche, Alin Albor VERNON L. KELLOGG, Prof. of Entomology, Leland stanford Ji. Lmiz', Palo Alto, Cat. CHARLES F. KING . . . . . Master of Deiarborn Sitiool, Fuston, Hass. S. J. MAcLEAN, Asst. Prof. of Ecomemids, Leland Stanford Jr. Ema', Palo Alto, Cal. FOREST RAY MOULTON, Assistant Professor in Astronomy, Unierersity of Chicago JACQUES W. REDWAY . . . . . . . . Althor, Nt. Tirnon, . $\mathrm{Y}$. ELLEN C. SEMPLE . . . . . Hriter in Anthrofogeografhy, Louiszille, Ky. FREDERICK STARR, Associate Prof. of Anthrofotogy', Lniz' of Chicago, Chicago, Ill. RALPH S. TARR, Professor of Phisical Geegrafhy, Cornell Cnizersity, Ithaca, 1. 1. SPENCER TRuTTER . . . . Protessor of Blology, Srathmore College, Pa. ROBERT DEC. WARD . Assistant F'rofessor of Climatology, Harad Unieresity

$$
\text { ASSOCHATE EDITORS FOR GREAT BRITAIN AVD CANADA }
$$

A. J. HERBERTSON, Lecturer in liegional Geografhy, Oxford Üninersity, En tand JOHN A. DRESSER . . . . . . . St. Francis College, Richmond, Quetec

TERUS OF SUBSCRIPTIUN

\section{$\$ 1.50$ a Year in Advance}

Single Copies, 20 Cents

Price in all foreign countries in the Universal Fostul Union, $\$ 1.90(10$ numbers $)$, postpaid Un sale with E. Nedirix, Ontook Fower, Edinburgh, Scotland

Subscriptions and advertisements should be sent to

$$
\text { THE JOLRVIL OF GEOGRAPHY }
$$

Room 550, r6o Adams. Street, Chicago, Ill, wr. Winona, Minn. 


\title{
THE GEOGRAPHICAL DEVELOPMENT OF BOSTON
}

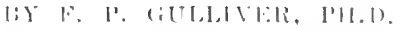

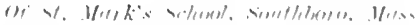

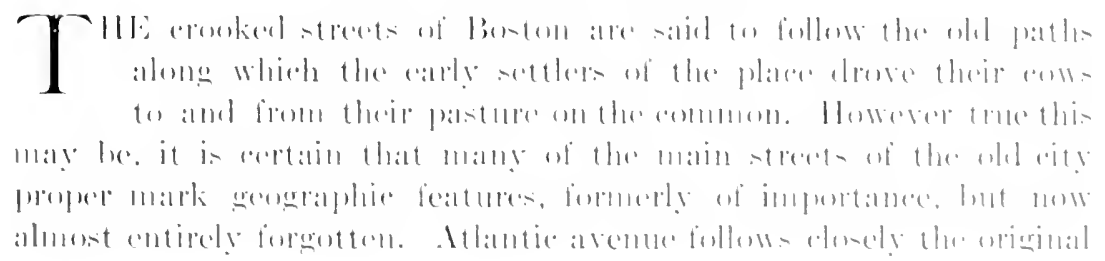


shore line. Washington street preserves in its curves the old road along the marrom nock of lamel. Which was the only comnection for a long time between the mainland and Boston peninsula with its three hills which save the name Tremont. Canseray street represents the dam to the ralliest tirlal mill pond, and Beacon street, the "Nlill-elan," was built later to hold back the waters of Back bay at high tirle to be weed for power at low tide. The enrve of Park stuare gives the shoreline of this Barek Bay, where the fathers and grandfathers of the present generattim neal to put on their skates to glicle orer the area now ocenpied by Trinity Church and the Public Library.

In a very marked legre Greater boston show its physiographic control in its development. The hills, valleys, islands, marshes, estuaries, ete., have helped or hindered the settlement and growth of the many village sites which are now inchuded in Metropolitan Boston. Many locations were made before 1650 around boston bay, (fee Map 1.) so that there were a large number of towns aromel the central "hub" at the foot of the three momtains which were later to be taken in to form the spokes of the wheel of greater Boston. Some portions of this area are still under distinct pelitical govermment, as Cambridge, Brookline, and Newton, but they no less truly form a part geographically of Netropolitan bestom.

The linits of the area of Greater Boston are variously drawn for different purposes. In order to show how the villages have grown tregether in the past and how they will continue to grow together in the future to form continuonsy inhabiterl areas, the ten mile limit fom the state House has been arlopted for this article; thus the following cities and towns are inchuled: Arlington, Behmont, Boston, Braintree, Brookline, Cambriclge, Chelsea, Jechan, Exorett, Hyde Park, Lexington, Lym, Malden, Medford, Molrose, Milton, Nahant, Neerlham, Newton, Quiney, Revere, Saugus, Sonerville, stonchan, Wakefield, Walthan, Watertown. Winchester, Winthrop, Wobum. (Fee map 5.) Portions of sone of these towns are very thinly sectled, but they all show growth from the centers toward their neighbors, atong railroads or highways, so that the attempt to join is clearly secen. In the above list under boston are inclucled the following centers which had an independent beginning: Brighton, Charkestown, Dorchester, East Boston, Janaica Plain, Roxluny, South Poston. In adclition it must be remembered that mamy of the above town began to grow in several plares, and are therefore matle up of several village sites. For example Nerton inclukles the following centers of growth; Newton, Newton 


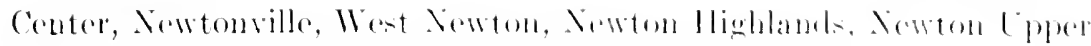
Falls, Newton lower lialls. Ambumblale, and Waban.

It will readily be seren that one must have intimate kmowlenge

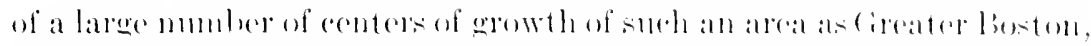

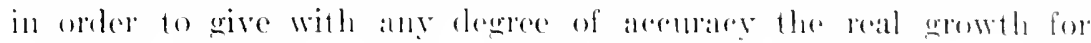

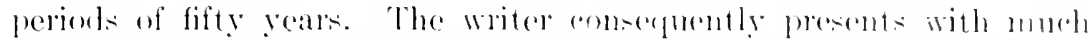
leseitamey the results of his stuely of this region, knowing that an ate-

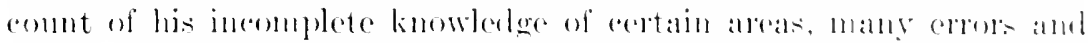

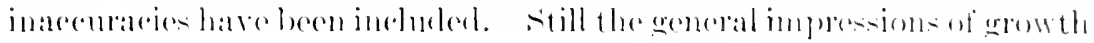

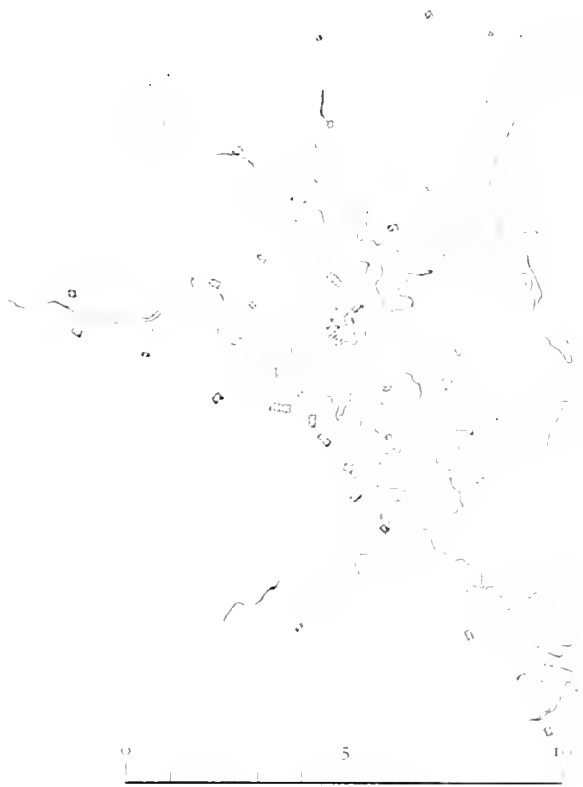

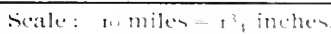

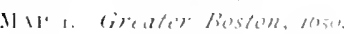

and foredepment a

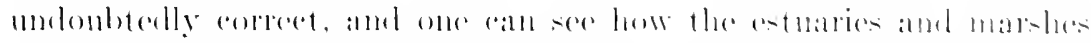

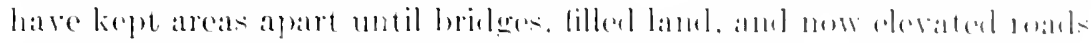

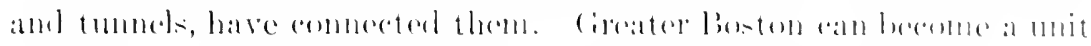

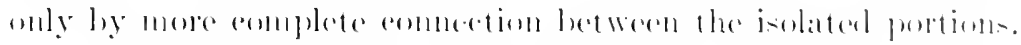

If there is interes emongh in this solies of malk to malke it worth

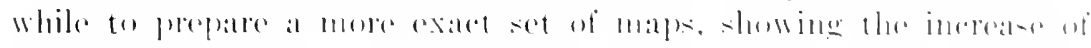

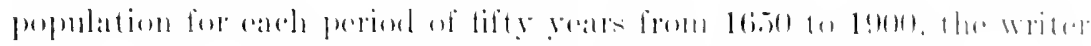

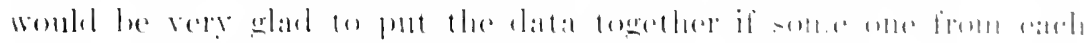

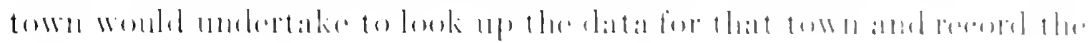




326 THE JUURNAL OF GEOGRAPHY June

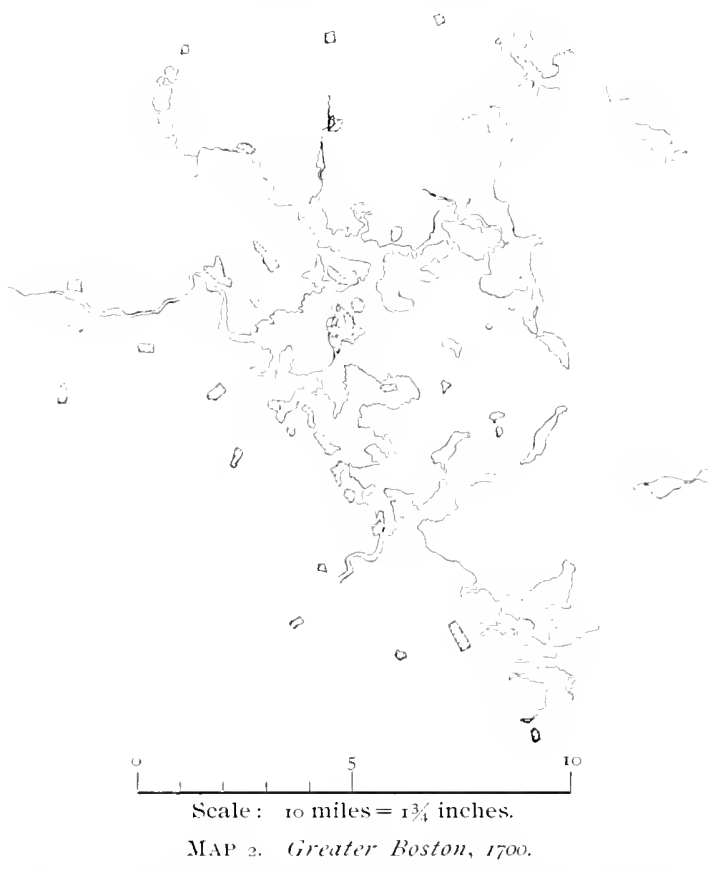

sane on a series of large scale town maps, for each period of fifty years. This can be done only by some one who has access to the town records and has the knowledge of local buildings. Such a set of maps would be of great interest to each town, and would be worth recording for future comparison, when many of these local units have been swallowed up in the extension of Boston.

There are a great many points of interest in the past, present, and future development of Boston, as shown on these maps, only a few of which can be mentioned here. Old Boston was at first very much isolated from the surrounding towns, the only connection by land being the neck on the southwest side, across which all wheeled vehicles had to pass along what is now Washington street. (Sce maps 1 and 2.) Thus Roxbury and Dorchester were the two center's most closely connected with Boston for some two hundred years, and through them hat to pass the stage coaches and produce-laden wagons from the towns to the west and south. A wagon to go from Cambriclge to Boston had to start westward, and then go sonthward, and finally eastwarl throngh Roxbury across the neck.

By 1800, however, two hridges harl been built to connect Boston 
with the towns to the west and north, one to Cambriglge and the other to Chatlestown. (see map :3.) At first. commmingtions had to be

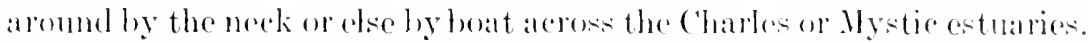

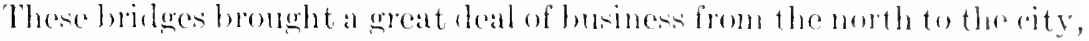
and the conters of population. Cambridge, somervillo, and charlestown increased much more rapidly. by 1850 a secomel bridge had been built to Cambrielge and a secombl to (hartestomm. (see mal, 4.)

The filling in of the back bay and the reclamation of the tirlal flats along the Charles river has been one of the greatent improvenent: of the past seventy-five yoars. By 1850, the mill-elan and two lines of raiboad hat asosed lack bay, and considorable filling hat been done on both sides of the neck. (Seremay 4.) Now in place of the narrow neck is a broad lamb comnection to the somth and west, and the eity is built almost continuously across this area to borehester, laoxlmry, Jamaica Plain, and Brookline. (See map is.) The tidal flats on the Cambridge side of the Charles have also hern fillod, and huilding has commeneed ujom them.

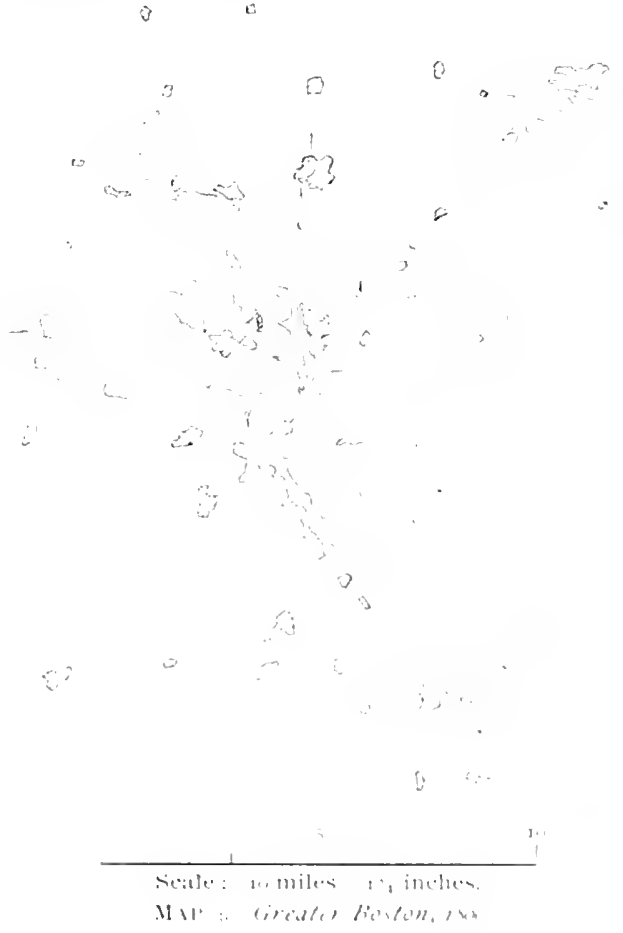




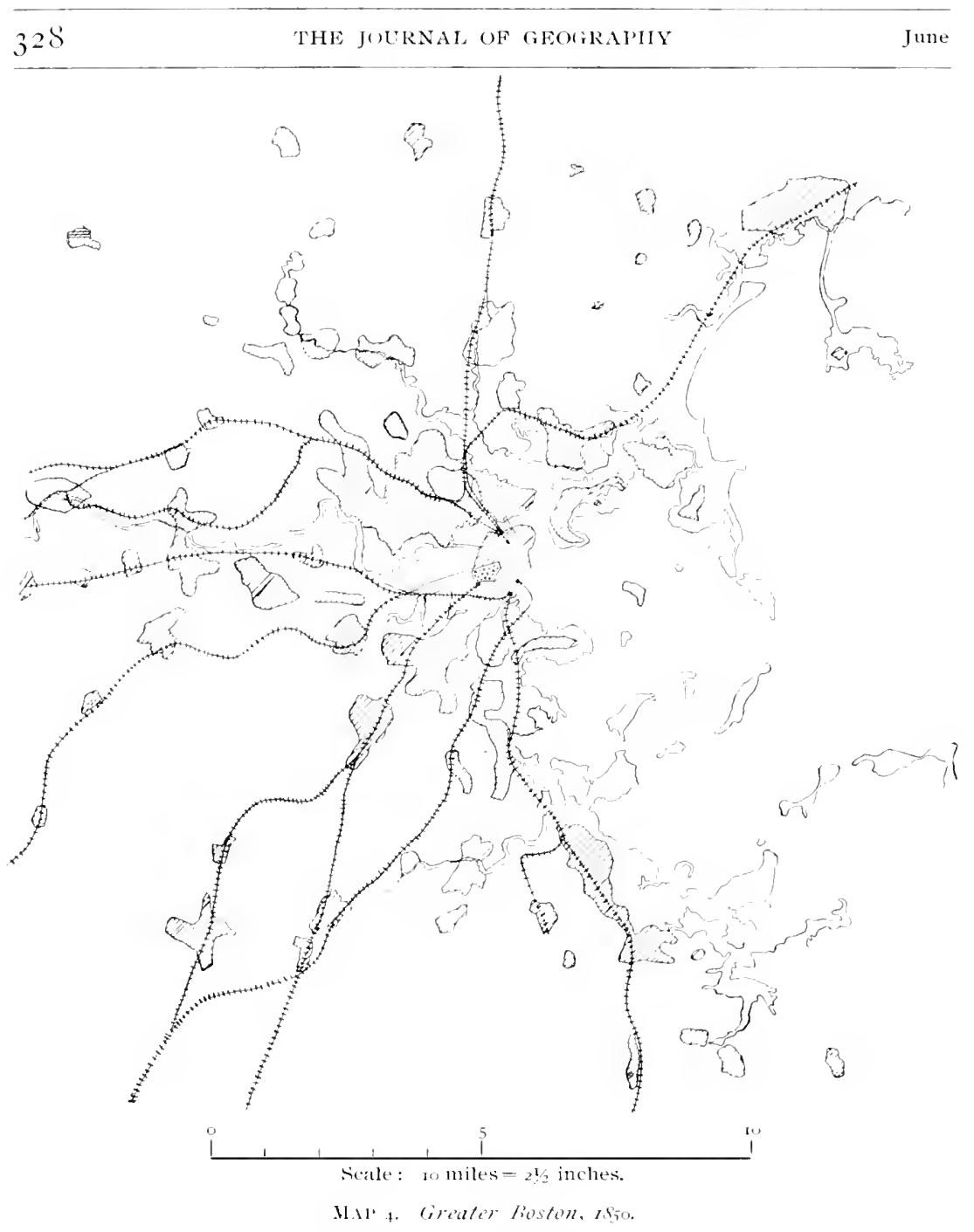

The growth and ratension of the wharf lines along the Boston, Charlestown, bast linston, and South Boston shore lines shows increased facilities for commeres. The plans for improvement aromel south Boston include the making of a good deal of new land and the formation of a marine park. There are a great many other signs of recent development which will not be mentioned here. There are, however, two great systems of improvenents to which reforence should be made. One of these is the extrnsive park and boulevard connections, which 


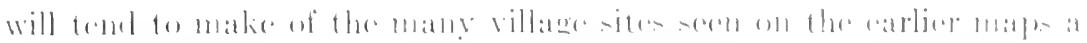

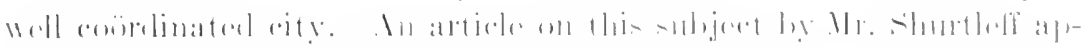

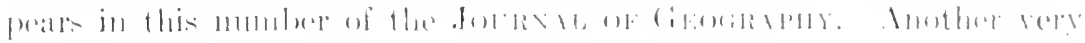

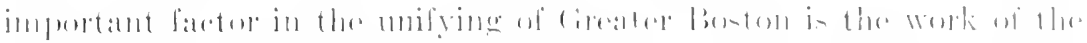

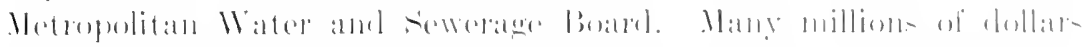

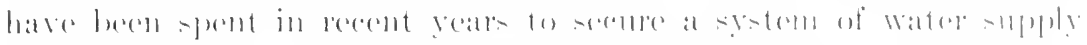

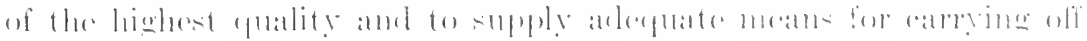

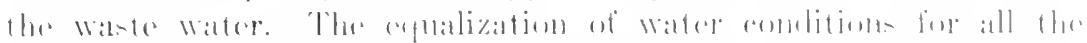

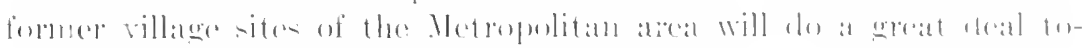

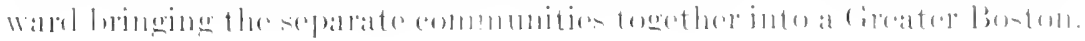

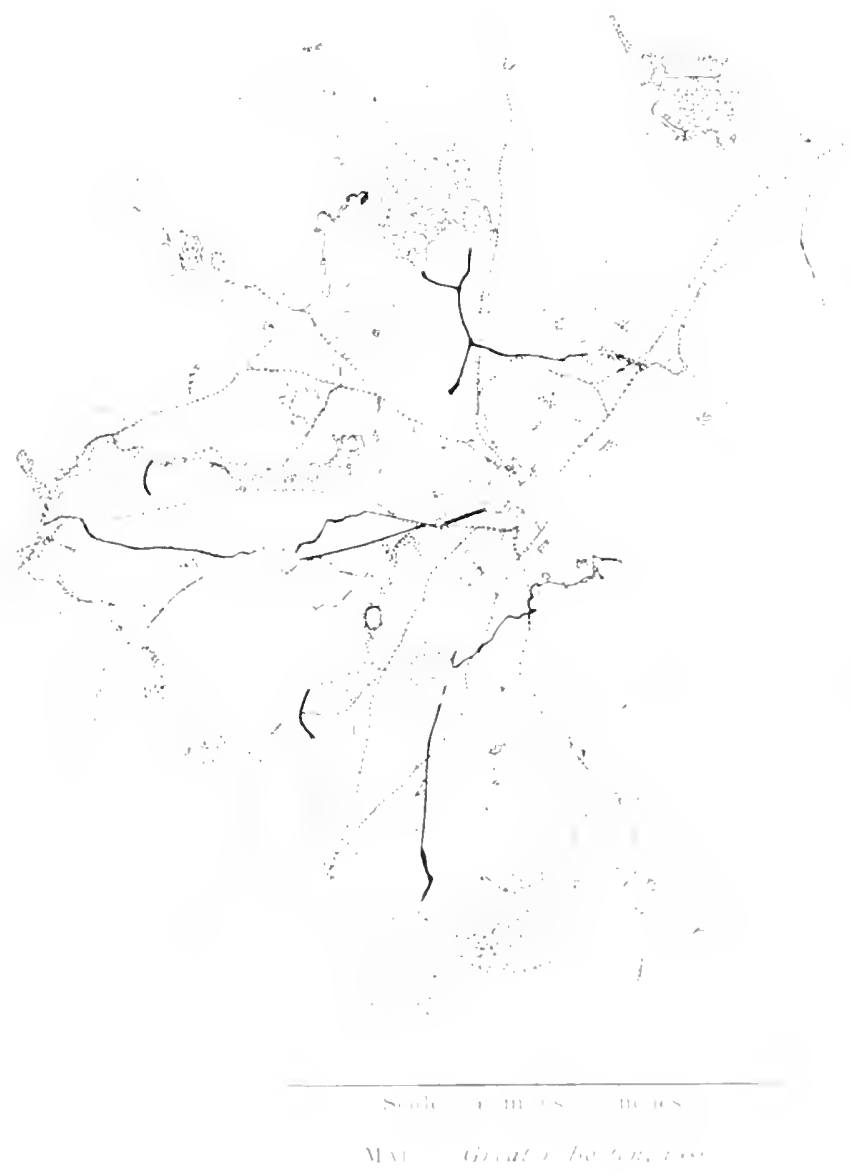





\section{THE JOURNAL OF GEOGRAPHY}

The Journal of Geography PUES WH PLFLILITRA

Price

Postage is Prepaid

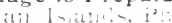

$11+\cdots,+1.0$

intitus.

Change of Address

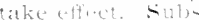

nincl-

Discontinuances

his

(i) at il

औit ith

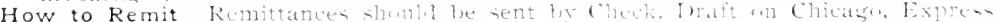

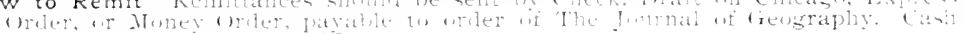

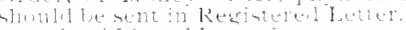

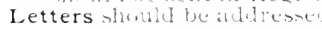

THE JOURNAL OF GEOGRAPHY

Room 560,160 Adams St., Chicago, Illinois

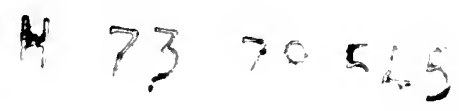





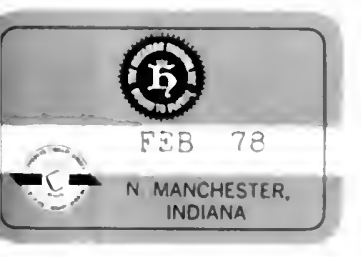


LIBRARY OF CONGRESS

|| || |||||||||||||||||||||||

00140779349 